
（垂直振動が跳躍限界を超える場合）

\author{
栗 田裕*1, 梅塚 紗百理*2

\section{Separation and Transportation of Works Using Elliptical Vibration (The Case of Vertical Vibration over the Jump Limit)}

\author{
Yutaka KURITA*3 and Sayuri UMEZUKA \\ *3 Department of Mechanical Systems Engineering, The University of Shiga Prefecture, \\ 2500 Hassaka-cho, Hikone-shi, Shiga, 522-8533 Japan
}

\begin{abstract}
Simultaneously separating and transporting works by using elliptical vibration with vertical vibration over the jump limit is described. In the condition of vertical vibration from 1.2 to $2.0 \mathrm{G}$, works with a smooth contact surface and those without a smooth contact surface can be separated and transported by adequately controlling the phase difference of elliptical vibration. Experimental results show that electronic parts with electric terminals can be separated at high speed in accordance with the difference between the shapes of the face and reverse sides. A change in the transportation characteristics of electronic parts without a smooth surface increases the speed of the separation and transportation. The difference between the transportation characteristics of parts without a smooth surface and those of parts with a smooth surface has increased. We clarified that the change in the transportation characteristics was derived from the jumps of parts by observing the behavior of electronic parts during separation and transportation with a high speed camera.
\end{abstract}

Key Words: Vibration Control, Friction, Industrial Machine, Elliptical Vibration, Vibration Transportation, Separation

\section{1. 緒言}

楕円軌跡を描くように振動台を加振すると，振動台 上の物体は高速に搬送される ${ }^{(1),(2)}$. 水平方向と垂淔方 向の振動の位相を $90^{\circ}$ ずらし, 反時計回りの棈円振動 を与える之物体は右方向一搬送され，時計回りの棈円 振動を与えると物体は左方向一搬送される. 位相差が $\pm 90^{\circ}$ の楕円振動を利用した振動搬送では, 摩擦力が 効率よく物体に作用するため, 位相差が $0^{\circ}$ の直線振 動搬送に比べて数倍の搬送速度が得られる。この棈円 振動機械を，水平方向，垂直方向ともに，共振点付近 で加振するために，速度フィードバック制御や引込み 現象を利用した共振点駆動法が提案されている(3)い(5).

垂直振動が跳躍限界以下のとき，水平振動と垂直振 動の位相差を $10^{\circ}$ 付近に設定すると, 振動台上の物体 は, 摩擦係数の大きさに応じて, その場で停止したり, 右方向あるい性左方向へ移動したりする.この現象を

* 原稿受付 2008 年 9 月 16 日.

*1 正員, フェロー, 滋賀県立大学工学部(画 522-8533 彦根市八 坂町 2500).

*2 正員, (株)村田製作所野洲事業所(画 520-2393 野洲市大篠 原 2288).

E-mail : kurita@mech.usp.ac.jp
利用して, 前報では, 材料ごとの分別や, 電子部品や 平座金の表毫分別を実現しだ(日). しかし，停止位相差 付近で駆動するため，左右に分別する搬送速度が小さ く, 大量の部品が供給されると分別できなかった.

そこで，本研究では，跳躍限界を超える垂直振動を 与えて，物体を高速に分別搬送する方法について検討 する．垂直振動が跳躍限界を超える場合は，物体は跳 躍しながら搬送されると考えられ，跳躍限界以下の場 合とは異なる挙動を示す。この挙動の变化が分別搬送 に与える影響を検討する．まず，垂直振動の大きさに よる搬送特性の変化について調べる. 跳躍限界を超え ると搬送特性が大きく変化する物体と変化しない物体 があることを示し，高速な分別搬送の可能性を提示す る. 次に，電子部品や平座金を用いて，分別搬送の高 速化について検証する. さらに, 分別搬送時の挙動を 高速度カメラで観察し，跳躍限界を超えたときに搬送 特性が変化する要因について考察する。

\section{2. 楕 円振動 機 械}

図 1 に，本研究で用いた楕门振重機械の模式図を示す. 楕门振動の振幅と位相差を任意に与えられるように，水平 方向と垂直力向を独立して加振できる構造とした. 水平振 
動は鈶直に取り付けた 4 枚の平行板ばねで与え，垂直振動 は水平に取り付けた 2 枚の平行板ばねで与えた。振動台の 搬送面は長さ $180 \mathrm{~mm}$ ，幅 $30 \mathrm{~mm}$ で，材質は表面を酸化皮膜 処理したアルミニウム，搬送面表面の算術平均粗さ $R a$ は $0.432 \mu \mathrm{m}$ である．板ばねの厚さと長さを調整して，水平振 動, 垂直振動ともに固有振動数を $82 \mathrm{~Hz}$ にした. 次章以降の 実験では，駆動周波数を $82 \mathrm{~Hz}$ にして共振点駆動した. 装置 を共振状態て駆動するために，速度フィードバック制御を 用いて減衰を大きくし，駆動周波数と固有振動数が多少ず れても振幅や位相があまり変化しない上うにした．加振力 は，バイモルフ構造となるように板ばねに貼り付けた圧電 素子の変形で与えた，振動台上の物体の搬送速度は，搬送 面上の所定距離（100mm）を移動する時間から算出した。

\section{3. 垂直振動が跳躍限界以下の場合}

垂直振動が跳躍限界（振動加速度が 1.0G）以下のと きの分別搬送の原理と実験結果を簡単にまとめる.

図 2 に，楕円振動の位相差と物体の搬送速度の関係 (以下，搬送特性）を示す。図 2 は，前報(6)で示した シミュレーション結果および実験結果をもとに作成し た概念図である，楕円振動の位相差によって，物体の 搬送速度は大きさと方向が大きく変化する，位相差が $-80^{\circ}$ 付近のとき搬送速度は正方向に最大となり，位 相差が $100^{\circ}$ 付近のとき搬送速度は負方向に最大とな る.また，位相差が $10^{\circ}$ 付近のとき搬送速度はほぼ $0 \mathrm{~m} / \mathrm{s}$ となる.この位相差を停止位相差と呼ぶ.

物体と振動台との間の摩擦係数が大きくなると搬送 特性が右に平行移動する性質を利用して，物体を摩擦 倸数ごとに分別搬送できる．楕円振動の位相差 $\phi$ を摩 擦係数 $\mu_{2}$ の物体の停止位相差 $\phi_{2}$ に調節する（図 2 中 の一点鎖線）。このとき，摩擦係数 $\mu_{2}$ の物体の搬送速 度は $0 \mathrm{~m} / \mathrm{s}$ となり，その場で停止する.また，摩擦係数 $\mu_{1}$ の物体は負の搬送速度をもって負方向へ搬送され， 摩擦係数 $\mu_{3}$ の物体は正の搬送速度をもって正方向へ 搬送される.このように, 適切な楕円振動を与えると， 振動台上の物体は, 摩擦保数の大きさに応じて, 停止 したり, 正方向または負方向に搬送されたりするので,

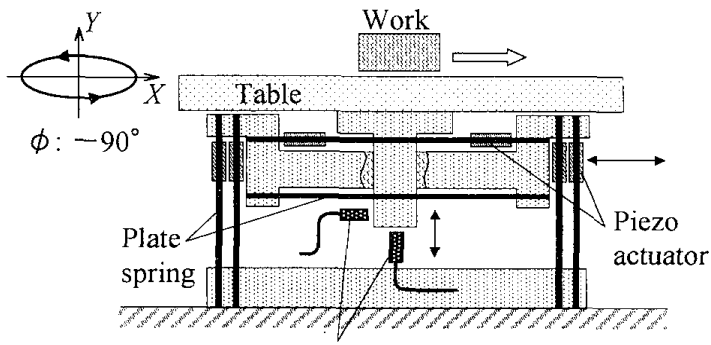

Displacement sensor

Fig. 1 Elliptical vibration machine
物体を摩擦係数ごとに分別できる.

摩擦保数の異なる物体の分別搬送の例として，電子 部品を用いて行った検証実験(6)を紹介する.

図3に，実験で用いた電子部品を示寸，電子部品は 横 $2.8 \mathrm{~mm}$ ，綐 $1.5 \mathrm{~mm}$ ，高さ $1.1 \mathrm{~mm}$ で，樹脂製の胴体に 金属製の爪が 3 本付いている．爪尔で接地する姿勢を表 向き，胴体で接地する姿勢を裏向きとした，表向きの ときは胴体と振動台の間に $55 \mu \mathrm{m}$ の陌間がある. 静止 摩擦係数 $\mu_{S}$ は表向きが 0.54 , 裏向きが 0.62 であった。

電子部品を表と裏に分別搬送するため, 電子部品の 搬送特性を調心゙た. 実験条件は, 水平振幅 $a$ を $0.4 \mathrm{~mm}$, 垂直振幅 $b$ を $0.037 \mathrm{~mm}$ とした. 水平振幅 $0.4 \mathrm{~mm}$ は実 験装置の出力限界であり, 垂直振幅 $0.037 \mathrm{~mm}$ は駆動周 波数 $82 \mathrm{~Hz}$ における跳躍限界である. 実験の結果, 表 向きの停止位相差は 8〜1 $11^{\circ}$, 裏向きは $24 \sim 28^{\circ}$ であ った，そこで，楕円振動の位相差 $\phi$ を表向きと裏向き の停止位相差のほぼ中間に当たる $17^{\circ}$ に調節した.こ のとき，表向きの搬送速度は $-0.020 \mathrm{~m} / \mathrm{s}$ ，裏向きの搬 送速度は $0.019 \mathrm{~m} / \mathrm{s}$ となった。

振動台の中央に 6 個の電子部品を表裹交互に一列に 並べて，表裏分別を行った，摩擦係数が小さい表向き は負方向に, 摩擦係数が大きい裏向きは正方向に搬送 されて，電子部品の表裏を分別できた。

同样の駆動条件において，大量（100 個）の電子部 品を振動台の中央に山積みにして供給し，表裏分別を 行った．所望の方向とは反対方向に引きずられて搬送 される電子部品がいくつかあり, 表裏を完全に分別で きなかった，跳躍限界駆動では，表向きと裏向きの搬 送特性の差が小さいので, 分別時の搬送速度が小さい。 そのため, 電子部品が他の部品を押しのけて所望の方 向に搬送されるのに十分な推進力が得られなかった。

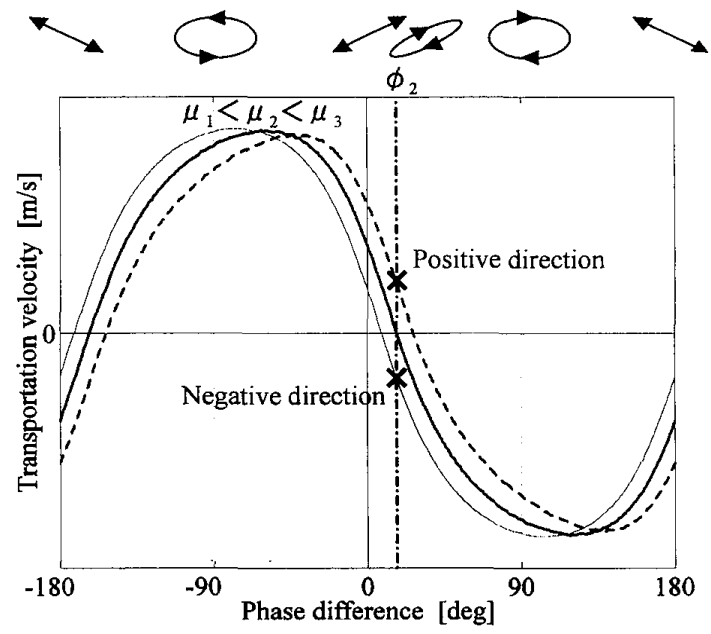

Fig. 2 Transportation velocity as a function of phase difference with various coefficients of friction 


\section{4. 垂直振動が跳躍限界を超える場合}

4 - 1 電子部品の表裏分別 大量の電子部品の表 裏分別を実現するために，垂直振動が跳躍限界を超え る場合の搬送特性について調べた．図 4 に，垂直振幅 による搬送特性の変化を示す. 実験条件は, 水平振幅 $a$ を $0.4 \mathrm{~mm}$ として，垂直振幅 $b$ を $0.015 \mathrm{~mm}(0.4 \mathrm{G})$ 〜 $0.052 \mathrm{~mm}(1.4 \mathrm{G})$ まで変化させた。

図 4(a)に，表向きの搬送特性を示す．図 4(a)から， 垂直振動が跳躍限界以下のときは，垂直振動が大きく なるにつれて搬送速度が大きくなることがわかる．垂 直振動が跳躍限界を超えると，表向きの搬送特性は右 方向に大きく平行移動した．このとき，停止位相差は $10^{\circ}$ 加 $90^{\circ}$ 付近まで増加した.

図 4(b)に，裏向きの搬送特性を示す，図 4(b)加ら， 垂直振動が跳躍限界以下のときは，表向き之同様に， 垂直振動が大きくなるにつれて搬送速度が大きくなる ことがわかる。しかし，垂直振動が跳躍限界を超えて も，裏向きの搬送特性はほとんど変化しなかった。こ のとき, 停止位相差は $30^{\circ}$ 付近でほぼ一定であった.

垂直振動が跳躍限界を超えたときの表向きと裏向き の搬送特性の違いを利用すると，分別時の搬送速度を 大きくできる. 図 5 に，垂直振動が $1.0 \mathrm{G}$ と $1.4 \mathrm{G}$ のと きの搬送特性を示す。

まず, ○印で示した垂直振動 1.0G のときの表裏分 別を検討する，位相差を $17^{\circ}$ に調節すると（図 5 中の 点線），表向き(の)は負の搬送速度，裏向き(○)は正の 搬送速度をもつ. 分別時の搬送速度を相対速度で評価 すると， $1.0 \mathrm{G}$ のときの相対速度は $0.039 \mathrm{~m} / \mathrm{s}$ であった。

次に, $\boldsymbol{\nabla} \nabla$ 印で示した垂直振動 $1.4 \mathrm{G}$ のときの表裏分

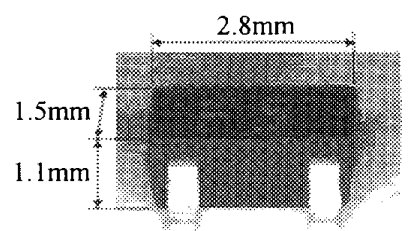

$\mu_{S}: 0.54$

(a) Face side

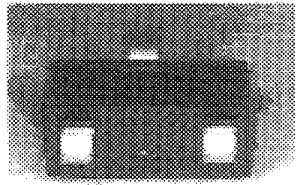

$\mu_{S}: 0.62$ $R a: 0.684 \mu \mathrm{m}$ (b) Reverse side

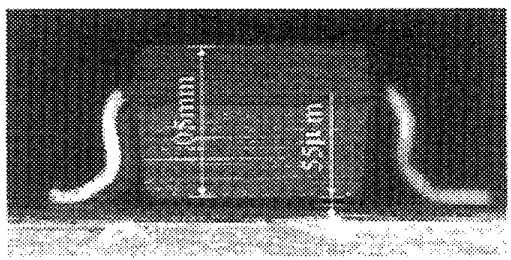

(c) Side view

Fig. 3 Electronic part
別を検討する，位相差を $60^{\circ}$ に調節すると（図 5 中の 一点鎖線），表向き $(\boldsymbol{\nabla})$ は正の搬送速度，裏向き $(\nabla)$ は負の搬送速度をもつ． 1.4G のときの相対速度は $0.158 \mathrm{~m} / \mathrm{s}$ であり，1.0G のときと比べて 4 倍の分別速度 が得らえた。跳躍限界を超える垂直振動を与えると， 表と裏の分別時の搬送方向が逆転するだけでなく，相 対速度が大きくなる。

分別搬送に適した駆動条件を検討するために，垂直 振動が停止位相差に与える影響を調べた。図 6 に，電 子部品 5 個分の垂直振幅による停止位相差の変化を示 す。実験条件は，水平振幅 $a$ を $0.4 \mathrm{~mm}$ として，垂直振 幅 $b$ を $0.0074 \mathrm{~mm}(0.2 \mathrm{G}) \sim 0.096 \mathrm{~mm}(2.6 \mathrm{G})$ まで変化させ た. 垂直振動 $2.6 \mathrm{G}$ は実験装置の出力限界である. 印 が表向き，○印が裏向きの停止位相差の平均值，バー がばらつきの範囲を表す。

図 6 から，1.0G を超える之，表向きの停止位相差が 大きく変化することがわかる. 1.0G 以下では，表裏と もに停止位相差があまり変化しなかった. しかし, $1.0 \mathrm{G}$ を超えると，表向きの停止位相差は大きく変化して， $90^{\circ}$ 付近まで増加した，さらに，2.2G を超えると表裏

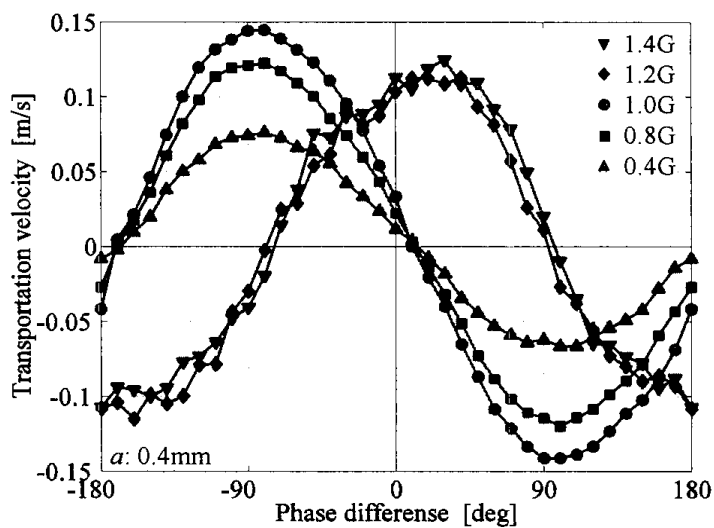

(a) Face side

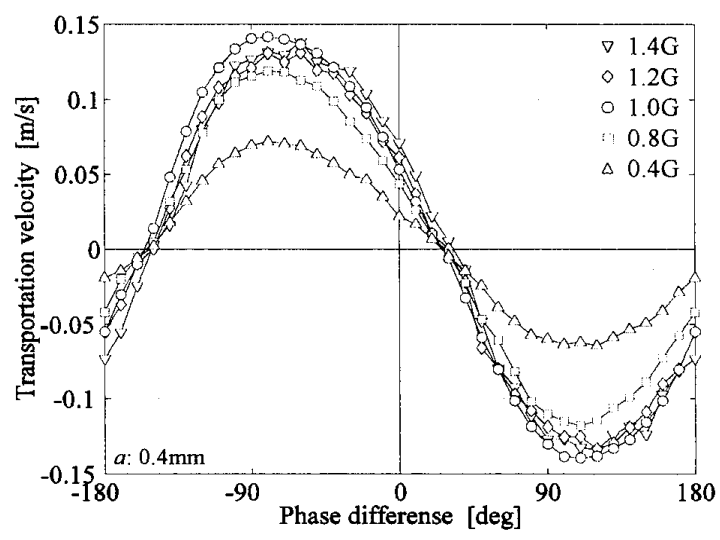

(b) Reverse side

Fig. 4 Transportation characteristics of electronic parts 
が頻繁に反転し，測定が困難になった，一方，裹向き の停止位相差は，1.0G を超えてもあまり変化しなかっ た．そのため，垂直振動が 1.2〜2.0G のとき，表向き と裏向きの停止位相差の差が大きく拡がった. そこで, 表と裹の停止位相差の差が大きく、ばらつきが小さい $1.4 \mathrm{G}$ 分分別搬送の実験条件とする。

図 7 に，電子部品 100 個をまとめて供給して，表裏 分別を行ったときの映像を示寸，実験条件は，水平振 幅 $a$ を $0.4 \mathrm{~mm}$, 垂直振幅 $b$ を $0.052 \mathrm{~mm}(1.4 \mathrm{G})$, 位相差 $\phi$ を $60^{\circ}$ とした. 白く着色した電子部品が裏向きである. 図 7 から, 表向きは正方向に, 裏向きは負方向に短時 間で搬送されて，大量の電子部品の表裏分別ができる ことがわかる. 山積みの状態で供給されても，振動台 上の部品は,すぐに均されて所望の方向一搬送される. 跳躘限界を超える垂直振動を与えることで，投入時の 配置に関係なく，大量の電子部品の表裏を短時間で分 別できた

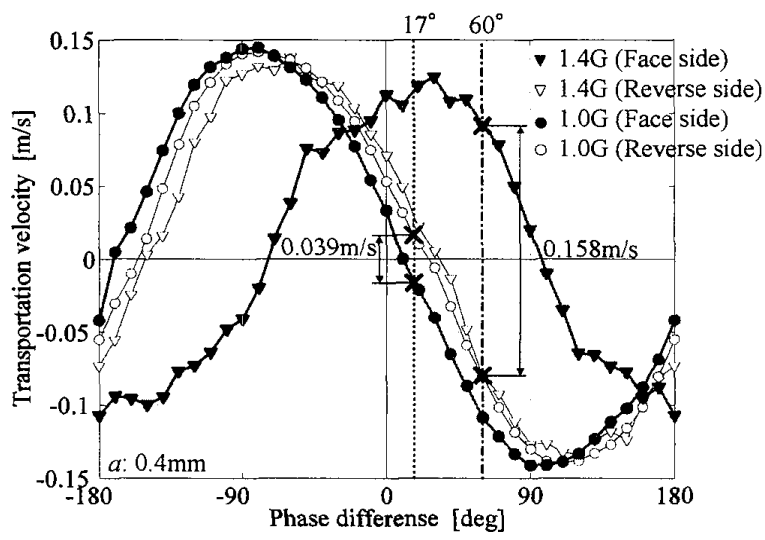

Fig. 5 Comparison of transportation velocity at separation

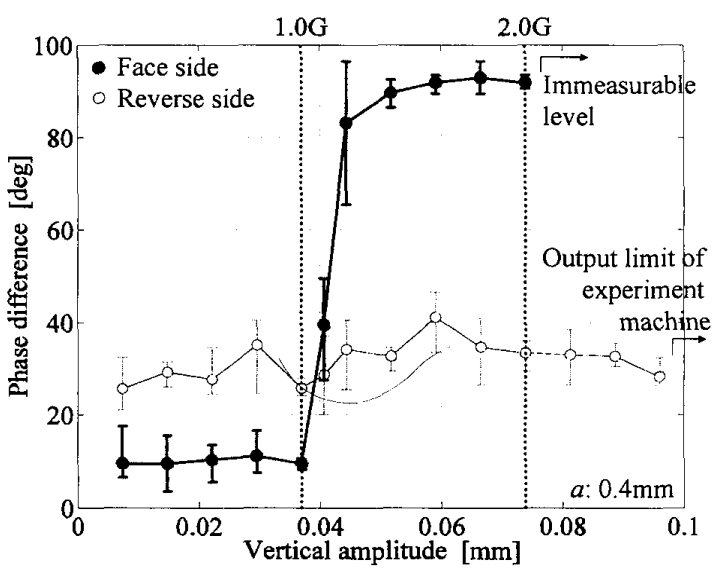

Fig. 6 Phase difference with zero transportation velocity as a function of vertical amplitude
4·2 平座金の表裏分別 次に，機械部品の分別 搬送の例として，平座金を表と裏に分別搬送する方法 について検討した．図 8 に，実験で用いた平座金を示 す．平座金は外径 $10 \mathrm{~mm}$ ，内径 $5 \mathrm{~mm}$ ，厚さ $1 \mathrm{~mm}$ で, 質量は $0.35 \mathrm{~g}$ である. プレス加工によって内外周部に ばりができている.ばりが下向きになる姿勢を表向き， ばりが上向きになる姿勢を裏向きとした。

図 9(a)に表向き，図 9(b)に裏向きの接触面形状を示 す。表面粗さ測定機（ミツトヨ社製 SURFTEST701） を用い，縦軸の分解能を $0.05 \mu \mathrm{m}$ として，平座金の半 径方向に 1.0um ごとに測定した．図9(a)から，表向き の場合は内外周部のばりで接地することがわかる。ば りの高さを 5 箇所測定したところ，内周部のばりの高 さは $68 \mu \mathrm{m} \sim 105 \mu \mathrm{m}$, 外周部は $69 \mu \mathrm{m} \sim 118 \mu \mathrm{m}$ であった. また，図 9(b)から，裹向きの場合注平坦な面で振動台 と接触することがわかる。このように平座金の表と裏 では，振動台との接触状態が異なっている.

跳躍限界を超える垂直振動を与えた棈円振動を利用 して，平座金の表裏分別を行った．図 10 に，垂直振動 が 1.4G のときの停止位相差付近における平座金の搬 送特性を示す．実験条件性，水平振幅 $a$ を $0.4 \mathrm{~mm}$, 垂 直振幅 $b$ を $0.052 \mathrm{~mm}(1.4 \mathrm{G})$ とした。印印表向き， 印は裹向きに対応する，表向きの停止位相差は $97^{\circ}$ ， 裹向きは $17^{\circ}$ であった. 位相差 $\phi$ を表と裏の停止位相 差のほぼ中間に当たる $50^{\circ}$ に調節すると（図 10 中の 一点鎖線），表向きの搬送速度は $0.064 \mathrm{~m} / \mathrm{s}$ ，裏向きは $-0.081 \mathrm{~m} / \mathrm{s}$ となる. $1.4 \mathrm{G}$ のときの相対速度は $0.145 \mathrm{~m} / \mathrm{s}$ となり，1.0G のときの相対速度 $0.033 \mathrm{~m} / \mathrm{s}^{(6)}$ と比べて約 4 倍の分別速度が得られた。

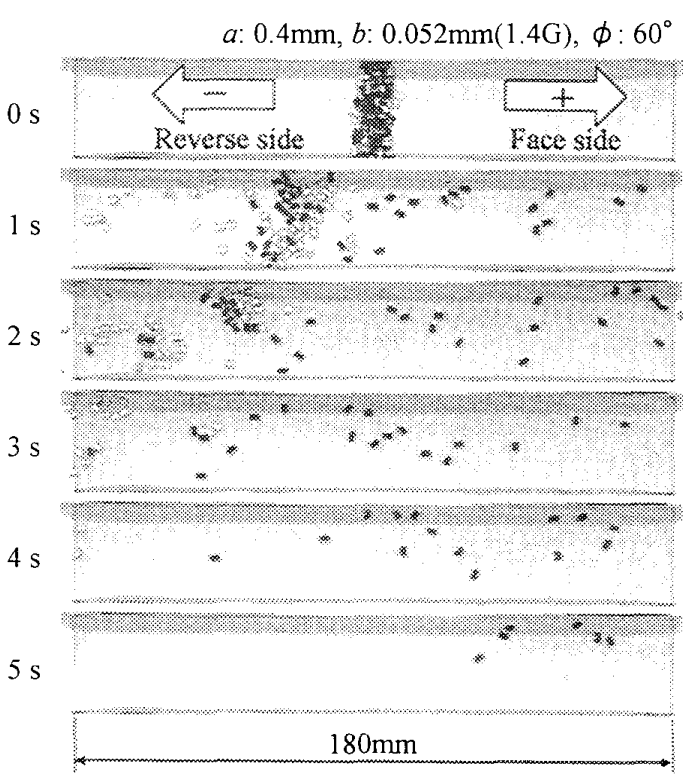

Fig. 7 Separation of a hundred electronic parts 
図 11 亿，平座金 14 個をまとめて供給して，表裏分 別を行ったときの映像を示す，着色した平座金が裏向 きである. 表向きは正方向に, 裏向きは負方向に短時 間で搬送されて, 表裏老分別できた. 垂直振動 $1.0 \mathrm{G} の$ ときの表裏分別では，平座金 6 個の分別に約 8 秒かか った( ${ }^{(0)} .1 .4 \mathrm{G}$ の垂直振動を与えることで, 約 2 倍の数 の平座金を 3 分の 1 程度の時間で分別搬送できた.

\section{5. 分別搬送が高速化した要因}

\section{$5 \cdot 1$ 分別搬送時の電子部品の挙動 跳躍限界を}

超える垂直振動を与えると, 表向きの電子部品の搬送 特性が変化する要因について検討する. 高速度カメラ

(ナックイメージテクノロジー社製 MEMRECAM fx RX-6）を用いて，分別搬送時の電子部品の挙動を観察 した. サンプリングは $6000 \mathrm{fps}$ ，有効画素数は $512 \times$ 384pixel, 分解能は $0.017 \mathrm{~mm} / \mathrm{pixel}$ である. 実験条件は, $4 \cdot 1$ 節の表裏分別と同様に, 水平振幅 $a$ を $0.4 \mathrm{~mm}$, 垂 直振幅 $b$ を $0.052 \mathrm{~mm}(1.4 \mathrm{G})$, 位相差 $\phi$ を $60^{\circ}$ とした.

図 12 に，分別搬送時の電子部品の映像を示す. 左が 裏向き，右が表向きである．重心を白点で示し，跳躍

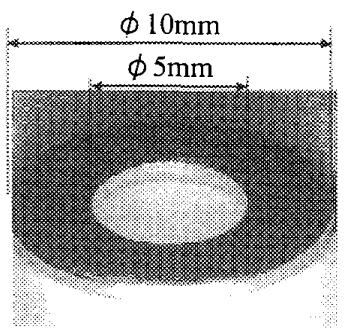

(a) Face side

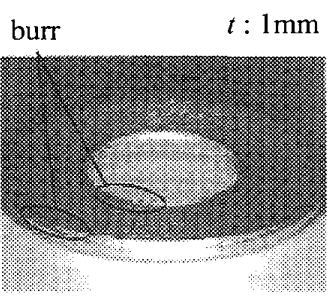

$R a: 0.754 \mu \mathrm{m}$

(b) Reverse side
Fig. 8 Plain washer

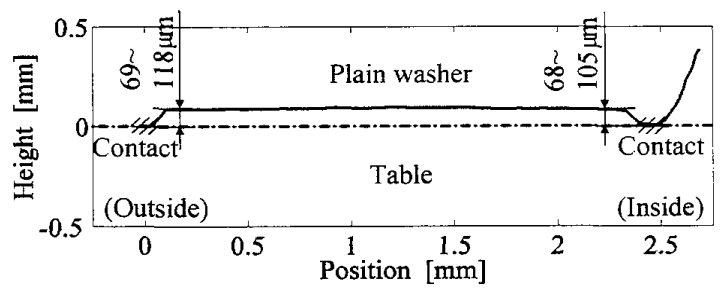

(a) Contact surface of face side

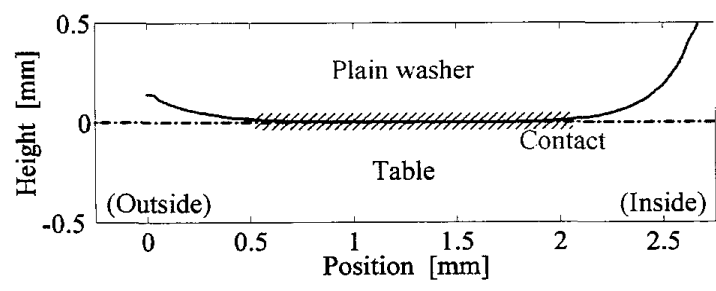

(b) Contact surface of reverse side

Fig. 9 Surface shape of a plain washer
の高さを矢印で示す，駆動開始から 0.15 秒付近まで， 表裏ともに左方向八搬送された。しかし，0.18秒老過 ぎたところで，表向きの部品の搬送方向が変わって右 方向一搬送された。このとき，表向きの部品は跳躍し ている，一方，裏向きの部品は跳躍することなく，左 方向一搬送された。このことから，搬送特性が変化す る要因は電子部品の跳躍であると考えられる。

図 13 に，図 12 の表裏分別における振動台と電子部 品の変位を時間軸波形で示寸．変位の算出には，2 次 元運動解析ソフト（ディテクト社製 DIPP-Motion 2D） を用いた. 図 12 の作成に用いた映像データから，振動 台側面の 1 点と，表向きと裏向きの電子部品それぞれ の重心の水平方向変位と垂直方向変位を算出した，点 線は振動台，太害線は表向き，細実線は裏向きに対応 する.

図 13 の上段は, 振動台之電子部品の水平方向の変位 $X, x$ を表す．振動台の水平方向振動は，振幅 0 の初 期状態から徐々に大きくなり，時刻 0.15 秒付近でほぼ 目標振幅の $0.4 \mathrm{~mm}$ に到達する.この振動台の水平振動 の成長に合わせて，表向きおよび裏向きの電子部品と

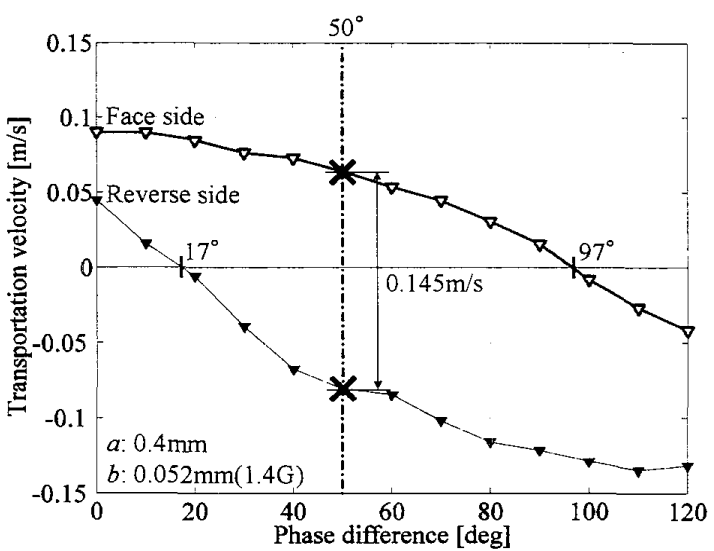

Fig. 10 Transportation characteristics of plain washers

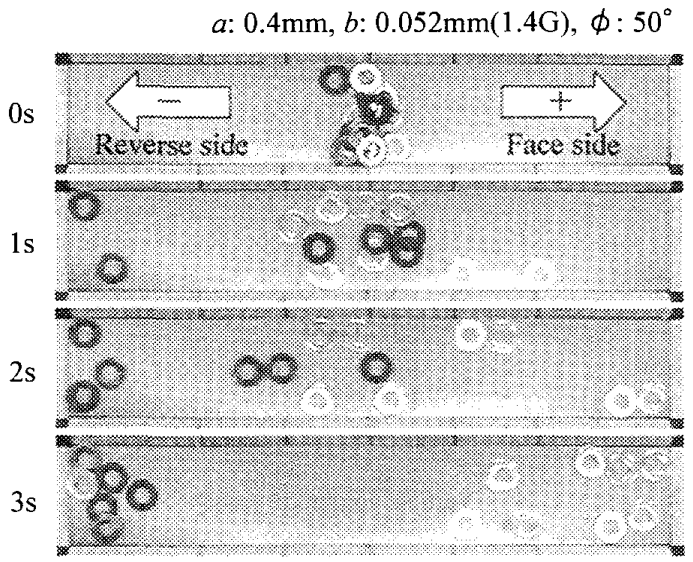

Fig. 11 Separation of fourteen plain washers 
もに搬送速度が次第に大きくなり，0.1 秒を越えたあた りで一定速度になっている，裏向きの電子部品は，そ のままの速度で負方向一搬送されているが，表向きの 電子部品は， 0.15 秒 $~ 0.18$ 秒付近で搬送方向が反転し て正方向一般送されている.

図 13 の下段は, 振動台と電子部品の垂直方向の変位 $Y, y$ 表す. 表向きおよび裏向きの電子部品ともに， 初めは振動台と一体となって運動する．裹向きの電子 部品は最後まで振動台と一体となって運動しているが, 表向きの電子部品は 0.1 秒付近で振動台から跳躍する ようになる．跳躍が大きくなる 0.13 秒あたりから，負 方向一の搬送速度が小さくなり， 0.15 秒 0.18 秒付近 て搬送方向が反転している。

次に，物体が跳躍しない場合は左方向一搬送され，

$a: 0.4 \mathrm{~mm}, b: 0.052 \mathrm{~mm}(1.4 \mathrm{G}), \phi: 60^{\circ}$

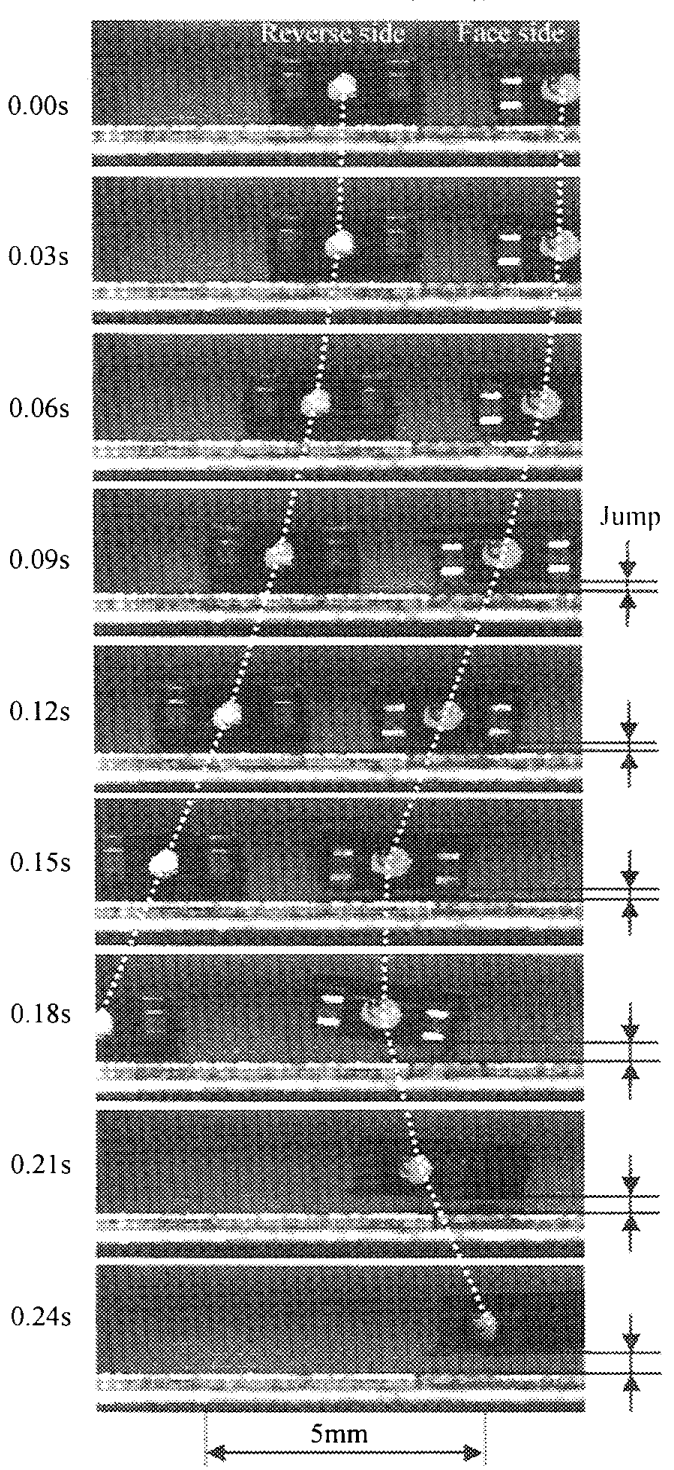

Fig. 12 Observation of the separation of electronic parts
物体が跳躍する場合は右方向に搬送されるしくみを考 える. 図 14 に，位相差が $60^{\circ}$ のときの楕円振動と物 体に働く摩擦力の方向を示す，振動台が右向きに運動 しているとき物体には正の摩擦力が働き，振動台が左 向きに運動しているときは物体に負の摩擦力が働く.

図 14(a)に，物体が跳躍しない場合を示す，楕円振動 の下半分のとき，物体は振動台に強く押し付けられる ため, この期間に物体が受ける摩擦力は大きくなる. 逆に，楕円振動の上半分では，摩擦力は小さくなる. そこで，物体が跳躍しない場合は，負の摩擦力が大き くなるので，物体は左方向へ搬送される.

図 14(b)に，物体が跳躍する場合を示す．跳躍限界を 超える垂直振動が加わると，棈円の最上点の少し前で 物体は振動台から浮き，楕円の最下点を少し過ぎたと ころで着地する．物体が跳躍している間は摩擦力が発

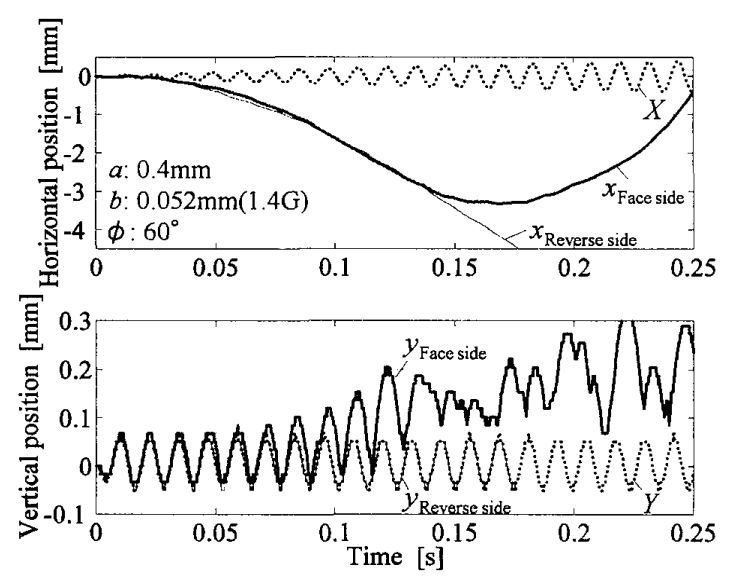

Fig. 13 Movement of the table and electronic parts

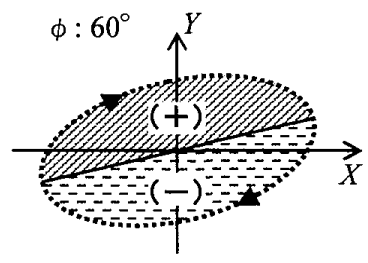

Work moves left

(a) The case of transportation without jumping

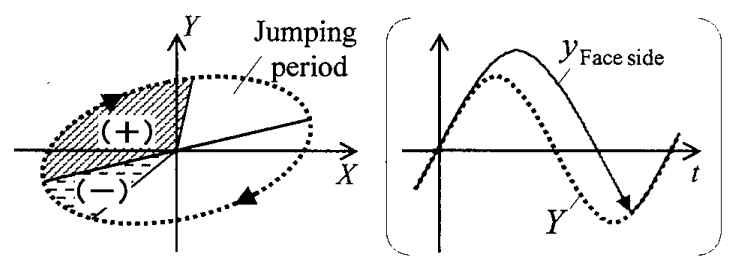

Work moves right

(b) The case of transportation with jumping

Fig. 14 Direction of the force on an electronic part 
生しない，そのため，負の摩擦力を受ける期間が短く なり，負方向の搬送速度が低下する，時間が経って跳 躍が大きくなると，負の摩擦力を受ける期間がさらに 短くなるため，搬送方向が逆転すると考えられる.

搬送特性が変化する要因は，物体の跳躍である。垂 直振動が跳躍限界を超える場合の分別搬送では，跳躍 する物体は右向きに，跳躍しない物体は左方向に搬送 されて，分別できる.

そこで, 跳躍限界を超える重直振動を与えた場合に， 跳躍する物体と跳躍しない物体に分かれる要因につい て考える. 電子部品の場合, 跳躍して右方向に搬送さ れるのは表向きである. 図 3 に示したように，表向き のときは，金属製の3 本の爪で接触しており，胴体と 搬送面との間に $55 \mu \mathrm{m}$ の隙間がある，一方，平坦な面 で隙間なく接触している董向きのときは，跳躍限界を 超える垂直振動を与えても跳躍しない.

\section{$5 \cdot 2$ 平坦な接触面をもつ物体の跳踓 跳躍限界}

（1G）を超える垂直振動を与えても跳躍しない平坦な 接触面をもつ物体が，どの程度の振動で跳躍するのか 検討した. 図 15 に，接触面が平坦な試験片を用いて搬 送実験したときの映像を示す。試験片は底面積 $S$ を $15 \mathrm{~mm} \times 10 \mathrm{~mm}$, 高さ $h$ を $6 \mathrm{~mm}, 12 \mathrm{~mm}, 18 \mathrm{~mm}$ とした. 材質は SUS303 で，算術平均粗さRaは $0.594 \mu \mathrm{m}$ であ る. 実験条件は, 水平振幅 $a$ を $0.4 \mathrm{~mm}$, 位相差 $\phi$ を $50^{\circ}$ として, 垂直振幅 $b$ を $0.052 \mathrm{~mm}(1.4 \mathrm{G}), 0.074 \mathrm{~mm}(2.0 \mathrm{G})$, $0.096 \mathrm{~mm}(2.6 \mathrm{G})$ と変化させた. 左から高さhが $6 \mathrm{~mm}$,
$12 \mathrm{~mm}, 18 \mathrm{~mm}$ の試験片を並べ，重心を黒点で示した.

図 15(a)に，垂直振動が 1.4G のときの結果を示す. 跳躍限界の 1.4 倍の垂直振動を与えても，どの試験片 も跳躍しなかった。このときの搬送速度は高さに依存 せずに約一 $0.05 \mathrm{~m} / \mathrm{s}$ の搬送速度をもち, 左方向一搬送さ れた。接触面が平坦であれば，垂直振動が跳躍限界を 超えても跳躍しないことがわかる.

図 15(b)に，垂直振動が 2.0G のときの結果を示す. 2.0G の垂直振動を与えても, 試験片は跳躍しているよ うには見えなかった。しかし，搬送速度に着目してみ ると，高さ $h$ が $18 \mathrm{~mm}$ の試験片の搬送速度は垂直振動 $1.4 \mathrm{G}$ のときと比べて約半分になった.

図 15(c)に，垂直振動が 2.6G のときの結果を示す. $2.6 \mathrm{G}$ の垂直振動を与えると, 高さhが $18 \mathrm{~mm}$ の試験片 は跳躍しながら右方向へ搬送された。このときの搬送 速度は $0.068 \mathrm{~m} / \mathrm{s}$ で，搬送方向が逆転した。また，高さ $h$ が $6 \mathrm{~mm}$ と $12 \mathrm{~mm}$ の試験片は跳躍しているようには 見えなかったが，高さhが $12 \mathrm{~mm}$ の試験片の搬送速度 は $1.4 \mathrm{G}$ のときと比べて 4 分の 1 になった. 重直振動を 大きくしたときに，試験片の高さによって，搬送速度 が小さくなったり，搬送力向が変化したりした。

図 16 に, 平坦な物体が実際に跳躍する限界について, 物体の高さに着目して調べた結果を示す。試験片の高 さhを $5 \mathrm{~mm} \sim 20 \mathrm{~mm}$ まで変化させた. 実験条件は, 水 平振幅 $a$ を $0.0 \mathrm{~mm}$ として, 垂直振幅 $b$ を $0.037 \mathrm{~mm}$ $(1.0 \mathrm{G}) \sim 0.096 \mathrm{~mm}(2.6 \mathrm{G})$ まで変化させた．定常状態にお
$0.0 \mathrm{~s}$

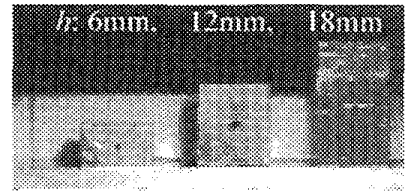

$0.1 \mathrm{~s}$

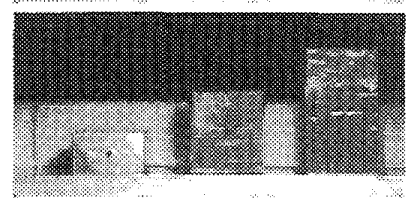

$0.2 \mathrm{~s}$

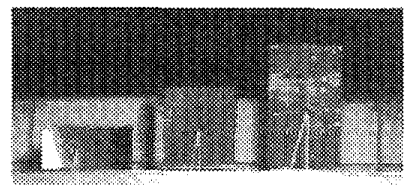

$0.3 \mathrm{~s}$

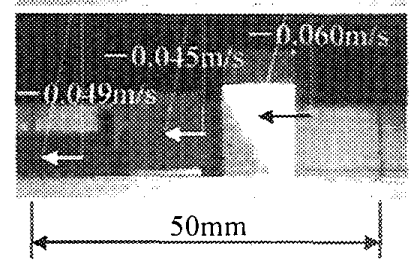

(a) $b: 0.052 \mathrm{~mm}(1.4 \mathrm{G})$
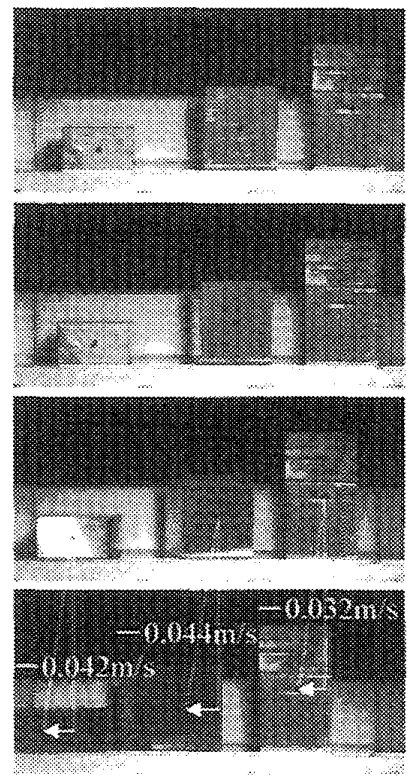

(b) $b: 0.074 \mathrm{~mm}(2.0 \mathrm{G})$ a: $0.4 \mathrm{~mm}, \phi: 50^{\circ}$
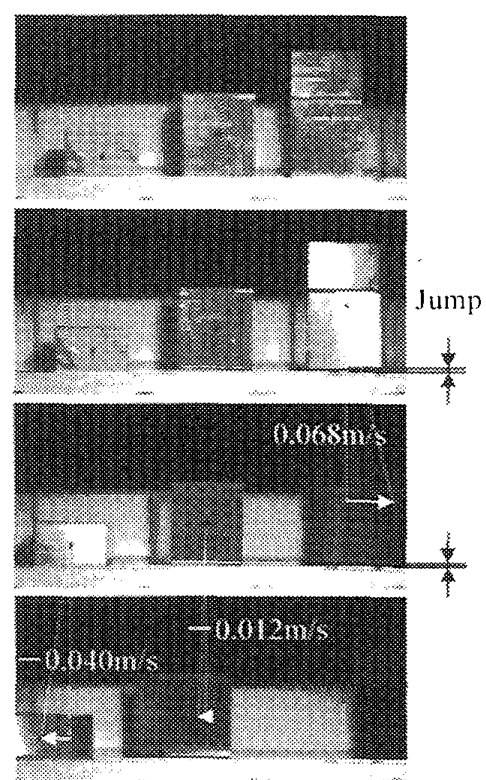

(c) $b: 0.096 \mathrm{~mm}(2.6 \mathrm{G})$

Fig. 15 Front view of transportation of three works 


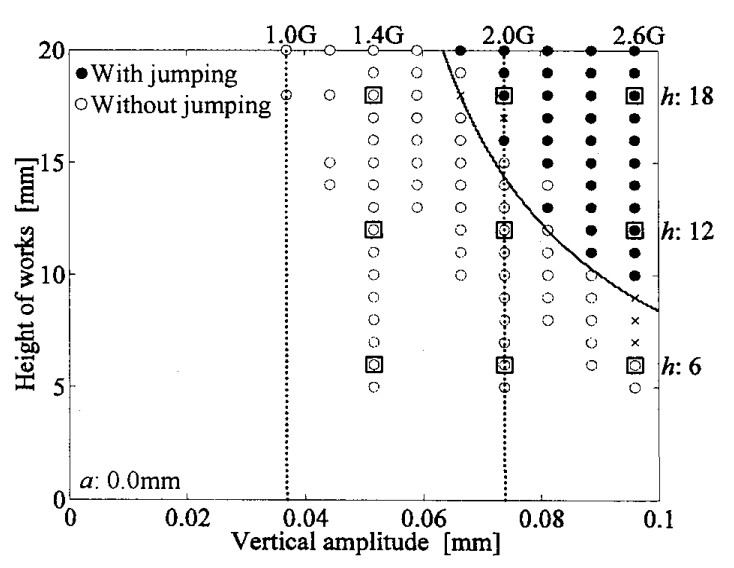

Fig. 16 Vertical amplitude on condition that works with various height jump

ける試験片の挙動を高速度カメラで観察し, 試験片と 振動台の間に隙間が生じた場合に試験片が跳躍したと 見なした. 分解能は $0.013 \mathrm{~mm} / \mathrm{pixel}$ である. 印は物 体が跳躍あり，○印は跳躍なし，×印は判別不能を表 す. 口印の条件は図 15 の実験条件に対応する. 図 16 から，物体の高さが高くなるにつれて，物体が跳躍す る限界の垂直振動が小さくなることがわかる.

垂直振動が $1 \mathrm{G}$ を超えても，平坦な接触面をもつ物 体が跳躍しない理由を考える．物体が跳躍するとき， 物体と振動台との間に周囲から空気が流れ込むア. 物体 と振動台との間の隙間が微小のときは，流入抵抗が大 きく，周囲からの空気の流入が妨げられる. そこで, 平面間の気圧は大気圧より低くなり，圧力差 $\Delta p$ が生 じる. そのため，物体を振動台に押し付ける力 $\Delta p S$ が 働く．物体が高くなるほど跳躍しないためには大きな 押付力が必要となる，しかし，圧力差による押付力は 物体の平面度に依存して定まるため，物体が高いほど 跳躍する限界の垂直振動は小さくなる.

平坦な接触面をもつ物体と振動台との間に，どれく らいの圧力差が発生しているのかを推測する. 振動台 が楕円の最上点のときに，物体に働く垂直抗力は $N=\rho \operatorname{Sh}\left(g-b \omega^{2}\right)+\Delta p S$ である. $\rho$ は鉄の質量密度, $g$ は重力加速度， $\omega$ は楕円振動の角周波数である. 重 直振動が跳躍限界を超える条件において，物体が跳躍 しないために必要な押付力は, $\Delta p S \geq \rho S h\left(b \omega^{2}-g\right)$ で 表され $(\because N>0)$ ，物体が実際に跳躍する限界の高 さは, $h=\Delta p / \rho\left(b \omega^{2}-g\right)$ となる. 図 16 に, 圧力差 $\Delta p$ を $1100 \mathrm{~Pa}$ と考えたときの物体の跳躍限界を太線で示 す.この太線は，実際の跳躍の有無の境界と一致して いるので, 圧力差 $\Delta p$ は $1100 \mathrm{~Pa}$ と推定できる.

高さが $20 \mathrm{~mm}$ もるる鉄のような重量物でも，重直振
動 $1.4 \mathrm{G}$ のとき跳躍しなかった。これより，様々な形状 や大きさの部品に関して, 接触面が平坦な部品と平坦 でない部品（隙間のある部品）を高速に分別できると 考えられる.

\section{6. 結 論}

本研究では，垂直振動が跳躍限界を超える条件にお いて，楕円振動を利用して物体を高速に分別搬送する 方法を検討した. 主な結果を次に示す。

（1）跳躍限界を超える 1.2〜2.0G の垂直振動を与え た楕円振動を利用して，接触面が平坦な部品と平坦で ない部品を高速に分別搬送できる.

(2) 分別搬送の高速化が実現したのは, 跳踓限界を 超える垂直振動を与えたときに，接触面が平坦でない 部品の搬送特性が大きく変化して, 平坦な部品の搬送 特性との差が拡がったためである.

(3) 接触面が平坦でない部品の搬送特性が変化した 要因は，部品の跳躍である。

（4）接触面が平坦な部品は，跳躍限界を超える垂直 振動を与えても跳躍せず，搬送特性も変化しない.

\section{文献}

(1) Okabe, S., Yokoyama, Y. and Jinbo Y., Vibratory Conveying by Elliptical Vibration, Journal of the Japan Society of Precision Engineering, Vol.40, No.477 (1974), pp.840-845.

(2) Yokoyama, Y., Okabe, S., Ishikawa, K. and Koizumi, K., Vibration applied technology (in Japanese), (1992), pp.93-98, Kogyo Chosakai Publishing, Inc.

(3) Muragishi, Y., Kurita, Y. and Matsumura, Y., Synchronization Driving of Elliptical Vibration Machine, Transactions of the Japan Society of Mechanical Engineers, Series C, Vol.69, No.684 (2003), pp.2005-2010.

(4) Muragishi, Y., Kurita, Y., Matsumura, Y. and Nakagawa, J., Driving at Resonance Point of Elliptical Vibration Machine Using Velocity Feedback, Transactions of the Japan Society of Mechanical Engineers, Series C, Vol.70, No.693 (2004), pp.1251-1257.

(5) Muragishi, Y., Kurita, Y., Matsumura, Y. and Nakagawa, J., Driving at Resonance Point of Elliptical Vibratory Machine Using Frequency Entrainment, Transactions of the Japan Society of Mechanical Engineers, Series C, Vol.71, No.712 (2005), pp.3381-3387.

(6) Kurita, Y., Matsumura, Y., Umezuka, S. and Nakagawa, J., Separation and Transportation of Works Using Elliptical Vibration (The Case of Vertical Vibration under the Jump Limit), Transactions of the Japan Society of Mechanical Engineers, Series C, Vol.74, No.743 (2008), pp.1710-1717. 